\title{
A REVIEW OF THE AMERICAN BEES OF THE GENUS MACROPIS (HYMEN., APOIDEA)
}

\author{
By Charles D. Michener \\ University of California, Berkeley, Calif.
}

Since the genus Macropis has not previously been recorded in America west of eastern Colorado, it is of interest to find $M$. morcei, the most widely distributed of our species, in Montana, and a new form of M. steironematis in Washington State, an extension of the known range of the genus by well over one thousand miles.

A comparison of our species with the descriptions and figures of Old World forms shows that the North American species belong to Macropis s.str., not to the subgenus Paramacropis ${ }^{1}$. Indeed the genitalia and sternites of our species agree in all essential points with the figures of $M$. labiata given by Saunders ${ }^{2}$. There are, however, certain differences, both in the genitalia and in the sternites. In $M$. morcei and ciliata the lateral projections of the eighth sternite, slender in labiata, are mere angles, while in $M$. steironematis opaca, described below, they are broad, rather truncated anteriorly, and about as long as in labiata. In M. morcei the genitalia are very similar to those of $M$. ciliata but differ in the somewhat shorter outer ramus of the stylus. I have not been able to study the genitalia of $M$. patellata or typical $M$. steironematis.

If $M$. longilinguis Provancher ${ }^{3}$, described from the female, proves to be true Macropis, it is probably a synonym of ciliata or patellata. Scrapter andrenoides $\mathrm{Smith}^{4}$, which was referred to Macropis by Dalle Torre is placed in Pseudopanurgus by Cockerell ${ }^{5}$.

\footnotetext{
1Popov and Guiglia, 1936, Ann. Mus. Civ. Storia Nat. Genova, 59:287.

Popov, 1936, Proc. Royal Ent. Soc. London (B) 5:78.

${ }^{2}$ Saunders, 1882, Trans. Ent. Soc. London, pl. 10.

3 Provancher, 1888, Add. Faun. Ent. Can. Hym., p. 424.

${ }^{4}$ Smith, 1853, Cat. Hym. Brit. Mus., 1:121.

${ }^{5}$ Cockerell, 1904, Can. Ent., $36: 303$.
} 
Macropis steironematis opaca Michener n. subsp.

Male: Similar to M. steironematis but hind metatarsus dull, very minutely roughened on outer side; punctures of hind tibiæ smaller than in $M$. steironematis, the surface between them minutely roughened; punctures of vertex more numerous, leaving only very small impunctate regions; surface between punctures of vertex slightly roughened. Length $9 \mathrm{~mm}$.

Holotype: Morgan's Ferry, Yakima River, Washington, July 1, 1882, in the collection of the Museum of Comparative Zoölogy at Cambridge, Massachusetts.

Differs from the typical form of this species by the much duller surface of the legs and vertex.

\section{Macropis morcei Robertson}

Two specimens from Montana (no further data) are from the collection of the Academy of Natural Sciences of Philadelphia.
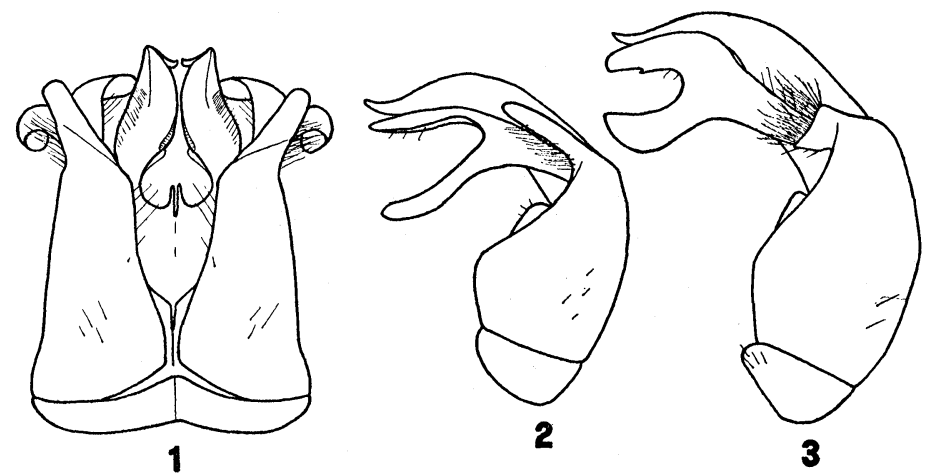

Fig. 1. 1, Dorsal view of genitalia of Macropis ciliata Patton; 2, Lateral view of genitalia of Macropis ciliata Patton; 3, Lateral view of genitalia of Macropis steironematis opaca Michener.

The following key will separate the American species of the genus:

1. Entire body closely punctured; length about $9 \mathrm{~mm}$. Male: Middle metatarsus broad, wider near base, and tapering apically; supraclypeal area yellow, and lateral face 
marks extending above antennal sockets; hind tibial spurs not inserted beneath teeth. .................... 2

-.Body much more sparsely punctate, punctures of abdomen separated by five or more times their diameters; length about $7 \mathrm{~mm}$. Male: Middle metatarsus slender, parallel sided; lateral face marks not extending above antennal sockets. 3

2. Male: Outer surface of hind metatarsus polished between the hairs; punctures of hind tibiae larger, the surface between them smooth; vertex shiny, with some fairly large, almost impunctate, smooth, areas. (East of Rocky Mountains) $\ldots \ldots \ldots \ldots \ldots \ldots \ldots \ldots$ steironematis ${ }^{6}$

-.Male: Outer surface of hind metatarsus dull, minutely roughened; vertex less shiny, with more punctures, the surface between them slightly roughened. Female: Unknown. (Washington State)............... steironematis opaca

3. Male: Hind tibial spurs not arising from beneath teeth; supraclypeal area black or with little yellow; lateral face marks reduced to short lines near sides of clypeus. Female: Pubescence of hind metatarsus largely black on outer side. morcei ${ }^{7}$

-Male: One or both hind tibial spurs arising beneath a tooth; supraclypeal area yellow; lateral face marks occupying entire space between clypeus and eye margin to a point above upper margin of clypeus. Female: Pubescence of hind metatarsus white. ....................... 4

4. Male: Outer hind tibial spur only arising beneath a tooth; lateral face marks ending about opposite middle of antennal sockets. Female: "Punctation, especially of scutel, sparse." $8 \ldots \ldots \ldots \ldots \ldots \ldots \ldots$.

-Male: Each hind tibial spur arising beneath a tooth; lateral face marks truncated and ending below the level of antennal sockets. Female: "Punctation, especially of scutel, dense." $8 \ldots \ldots \ldots \ldots \ldots \ldots \ldots$. . . . . . .

\footnotetext{
${ }^{6}$ Robertson, 1891, Trans. Am. Ent. Soc., 18:63.

7Robertson, 1897, Trans. Acad. Sci. St. Louis, 7:338.

8 Viereck, 1916, Hym. Connecticut, p. 720.

9Patton, 1880, Ent. Mon. Mag., 17:31.

${ }^{10}$ Patton, 1880, Ent. Mon. Mag., 17:33.
} 

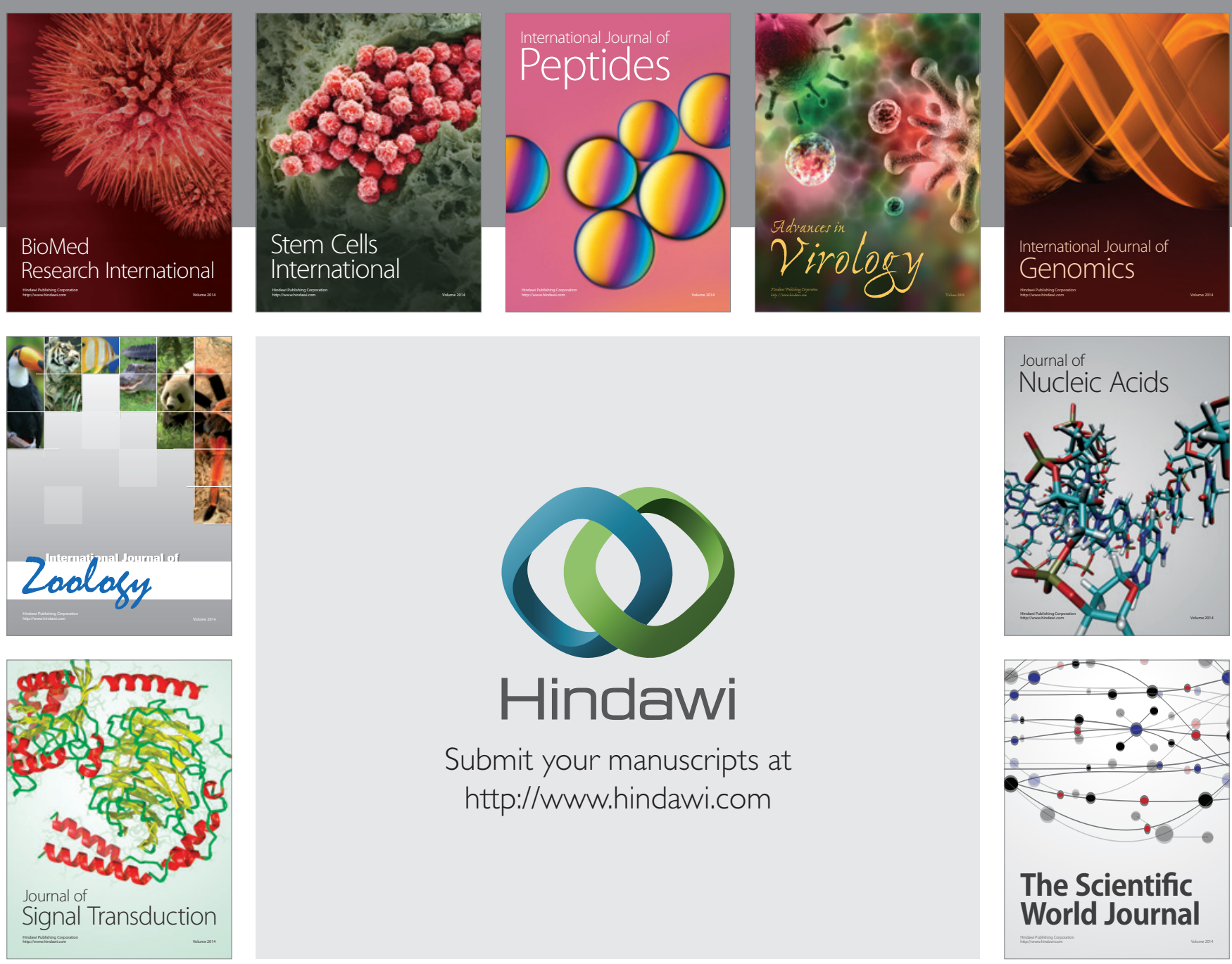

Submit your manuscripts at

http://www.hindawi.com
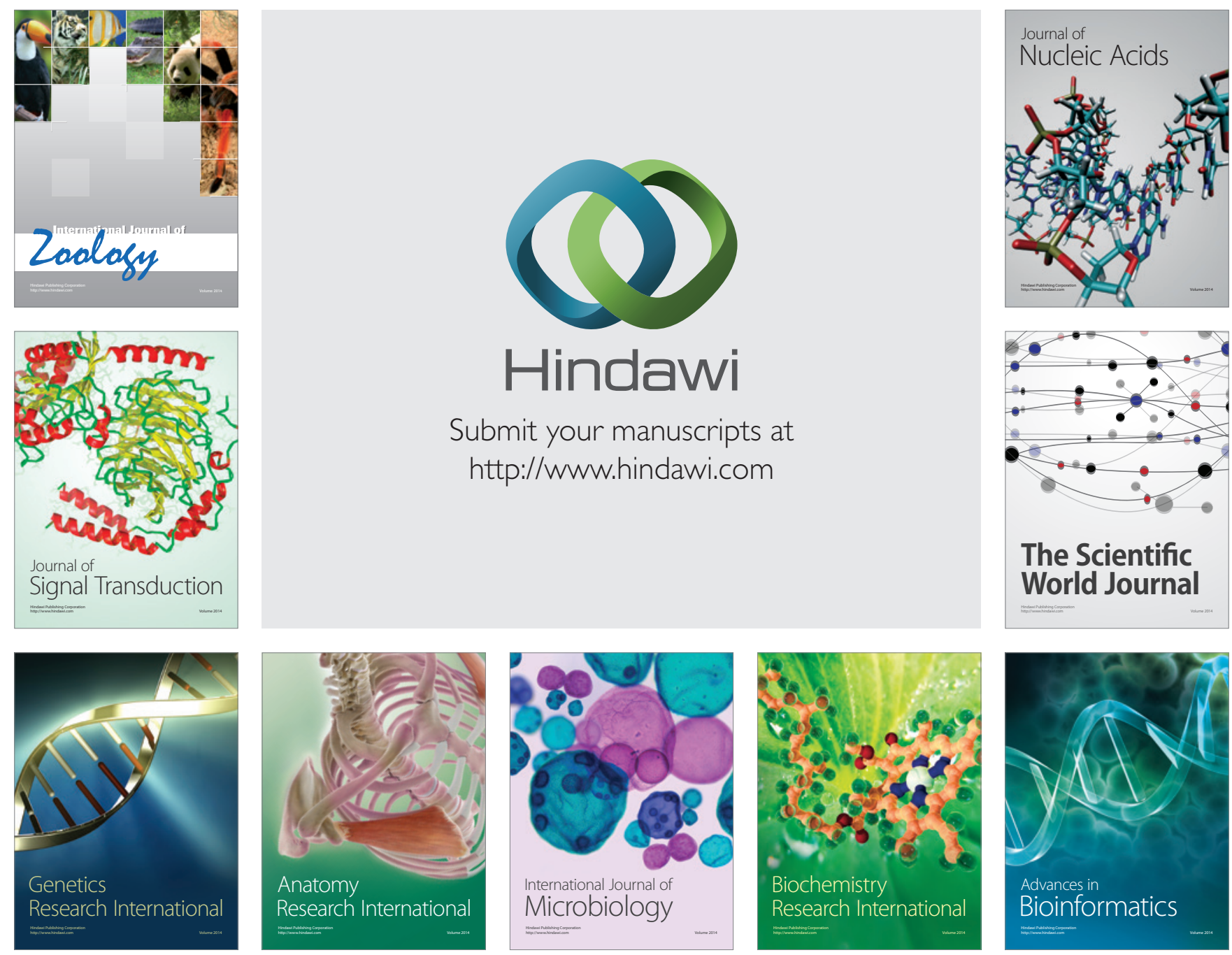

The Scientific World Journal
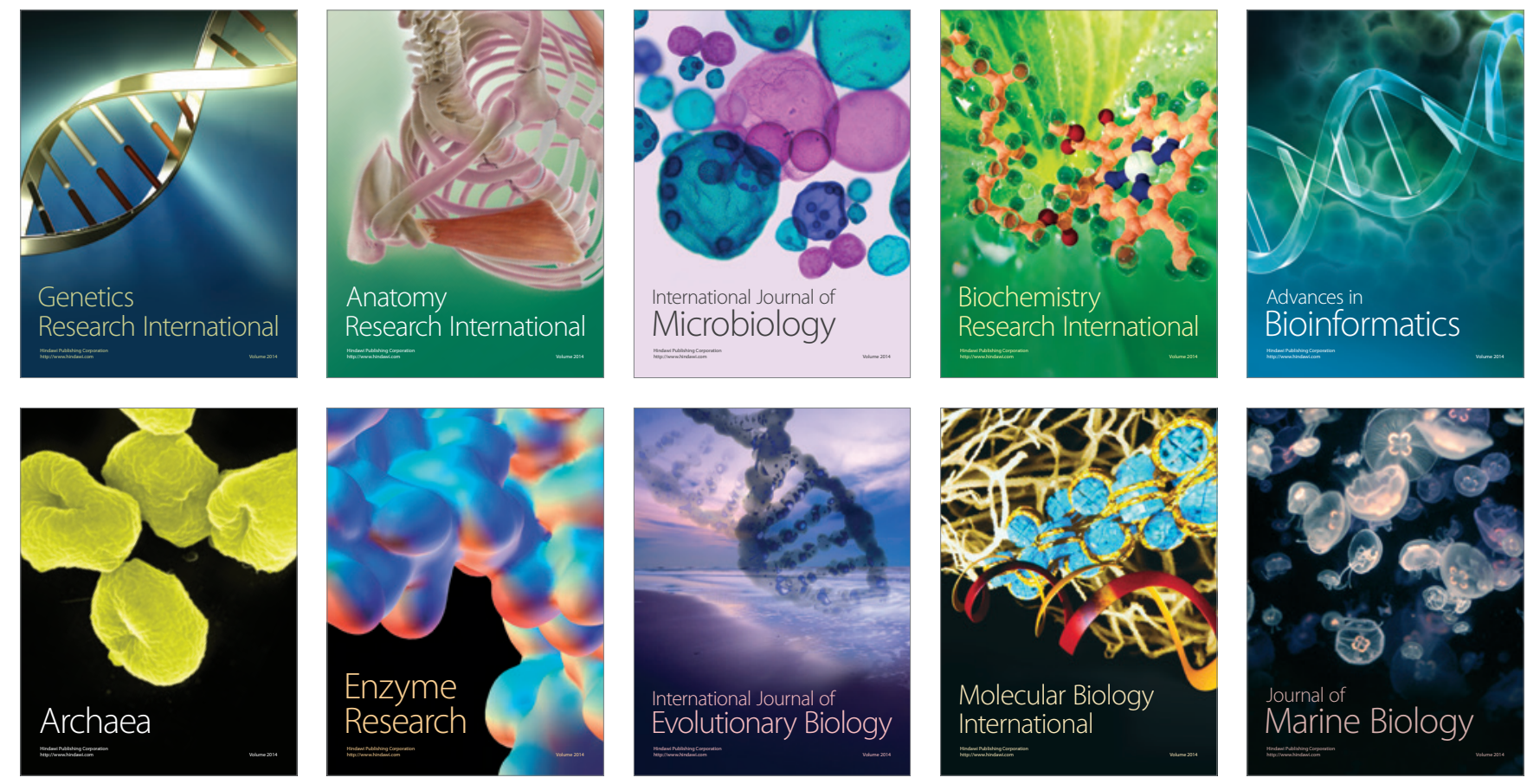